\title{
Perubahan Persepsi Melalui Pelibatan Masyarakat dalam Proses Analisis Mengenai Dampak Lingkungan (AMDAL) PLTGU Perak
}

\author{
Endang Susilowati ${ }^{1}$, Sukriyah Kustanti Moerad ${ }^{2}$ \\ UPT PMK Sosial Humaniora, Institut Teknologi Sepuluh Nopember, 61111, Surabaya, E-mail: \\ endangits@yahoo.com
}

\begin{abstract}
The residential area and industrial economy in Indonesia specifically East Java has grown rapidly. This is a challenge for National Electricity Board such as P.T. PLN Persero East Java to supply the energy sufficiently. Therefore P.T.PLN Persero through the branch company, P.T.Indonesia Power will build four (4) new plants with huge capacity more than 1,000 MW. One of the plant will be built in the administrative area of Perak Utara Village, Pabeaan Cantikan DistrictSurabaya City. The plant will be generated with gas and steam (PLTGU), that is a combined cycle between the electricity plant which is powered with gas (PLTG) and the electricity which is powered with steam (PLTU). The development of PLTGU is aimed for many benefits, such as: to fulfill electricity that has continually increased; to improve domestic, business or industry activities through continually electricity supply; as the peak loader of Java-Bali electricity supply system; and it is also aimed for supporting the 35,000 MW electricity government program. Even though there are many benefits of the development, it is often facing many problems in its implementation from community affected project around study area because of their negative perceptions. So it is important to conduct a community approach through project socialization and public consultation meeting (PKM) for gaining perception change, from negative to positive perception toward development activities.

Key Words: Perception change; energy supply adequacy; electricity plant powered with gas and steam (PLTGU); socialization and public consultation meeting (PKM); environmental impact assessment (AMDAL)
\end{abstract}

\begin{abstract}
Abstrak
Pertumbuhan dan perkembangan permukiman atau pun perekonomian industri di Indonesia khususnya di Jawa Timur saat ini telah berkembang begitu pesat, hal ini menjadi tantangan bagi P.T. PLN Persero distribusi Jawa Timur untuk memenuhi kecukupan energinya. Oleh karena itu P.T. PLN Persero melalui anak perusahaan P.T.Indonesia Power akan membangun 4 (empat) pembangkit baru berskala besar dengan kapasitas di atas 1000 MW. Salah satu pembangkit tersebut akan dibangun di Kelurah Perak Utara Kecamatan Pabean Cantikan Kota Surabaya. Pembangkit tersebut merupakan Pembangkit Listrik Tenaga Gas dan Uap (PLTGU), yaitu gabungan antara Pembangkit Listrik Tenaga Gas (PLTG), dan Pembangkit Listrik Tenaga Uap (PLTU). Pembangunan PLTGU Perak ini tidak hanya menggunakan proses yang ramah lingkungan tetapi juga bertujuan untuk menyediakan kebutuhan pasokan daya listrik yang terus meningkat; memperlancar kegiatan domestik, usaha atau industri melalui penyediaan daya listrik yang kontinyu; pemikul beban puncak pada sistem kelistrikan Jawa Bali; dan mendukung program 35.000 MW yang dicanangkan pemerintah. Meskipun besar manfaatnya rencana kegiatan pembangunan semacam ini akan mengalami kendala dalam implementasinya dari masyarakat di wilayah studi karena persepsi negatif terhadap rencana pembangunan, sehingga perlu dilakukan pendekatan kepada masyarakat melalui kegiatan sosialisasi dan PKM sehingga terjadi perubahan persepsi positif.

Kata Kunci: Perubahan Persepsi; Kecukupan Energi; Pembangkit Listrik Tenaga Uap (PLTGU); Kegiatan Sosialisasi dan Pertemuan Konsultasi Masyarakat (PKM); Studi Analisis Mengenai Dampak Lingkungan (AMDAL)
\end{abstract}

\section{Pendahuluan}

Pertumbuhan dan perkembangan permukiman maupun perekonomian industri di Indonesia khususnya di Jawa Timur saat ini telah berkembang begitu pesat, hal ini menjadi tantangan bagi P.T. PLN Persero distribusi Jawa Timur untuk memenuhi kecukupan energinya. Oleh karena itu P.T. PLN Persero melalui anak perusahaan P.T.Indonesia Power akan membangun 4 (empat) pembangkit baru berskala 
besar dengan kapasitas diatas 1000 MW. Energi listrik yang dihasilkan ini nantinya dengan proses ramah lingkungan, tidak menggunakan batu bara melainkan menggunakan gas dan uap sehingga pembangkit tersebut merupakan Pembangkit Listrik Tenaga Gas dan Uap (PLTGU), yaitu gabungan ( combined cycle) antara Pembangkit Listrik Tenaga Gas(PLTG), dan Pembangkit Listrik Tenaga Uap (PLTU). Pada proses PLTG digunakan mesin Gas Turbin Generator (GTC) sebagai penggerak, sedangkan pada proses PLTU memanfaatkan gas bekas yang keluar dari GTC setelah melalui proses Heat Recovery Steam
Generator (HRSG); uap yang dihasilkan digunakan untuk memutar Steam Turbine Generator (STG). Kombinasi dari gabungan pembangkit tersebut adalah listrik yang keluar dari masing-masing generator akan dikuatkan ke transformator dan selanjutnya dialirkan melalui tiang transmisi ke switch yard dan kemudian dikirim ke gardu induk melalui transmisi tegangan tinggi dan tegangan rendah. Pembangkit baru tersebut akan dibangun tersebar di 4 (empat) daerah Jawa Timur, yaitu: Gresik, Perak Surabaya, Grati Pasuruan, dan Tanjung Awar Awar.

Gambar 1. Skema Pembangkit Listrik Tenaga Gas dan Uap (PLTGU)

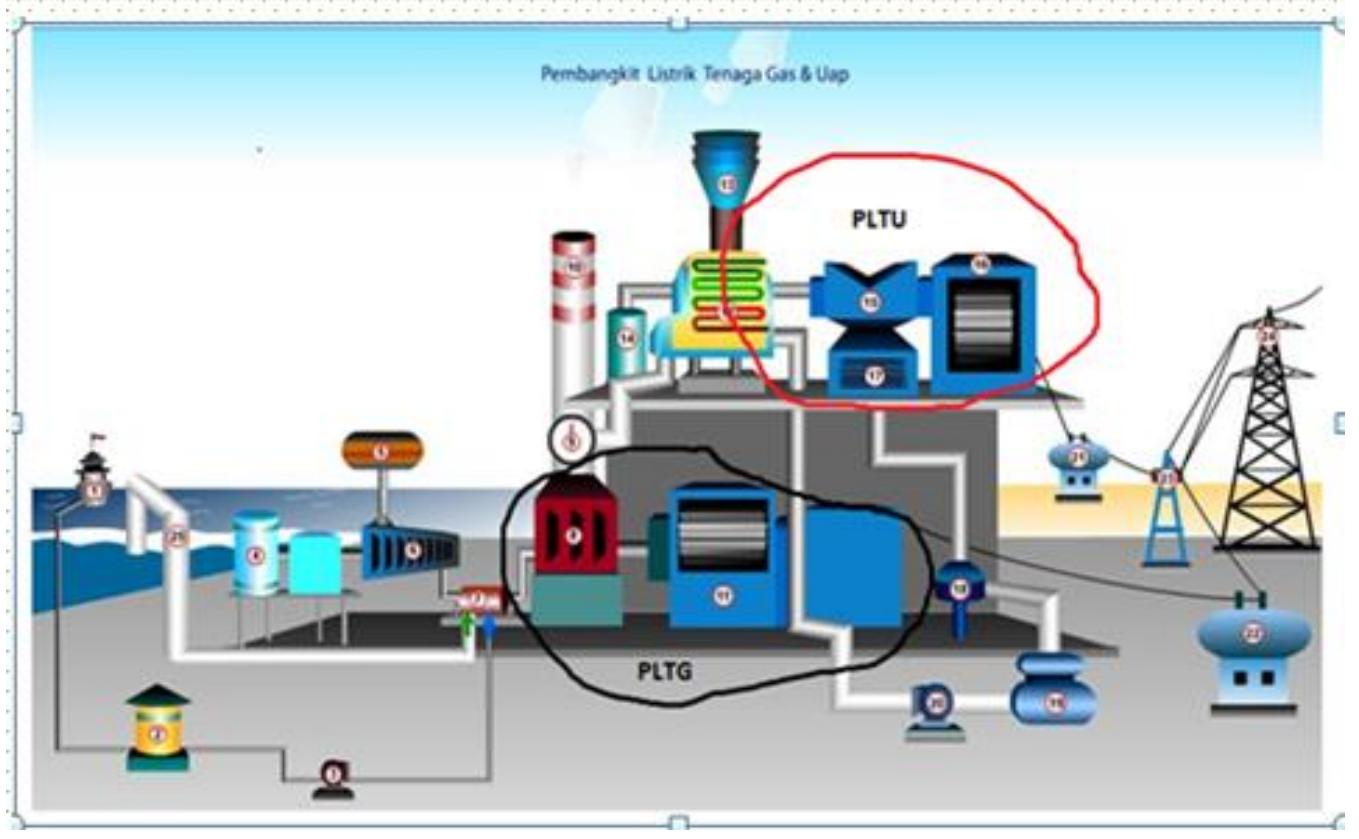



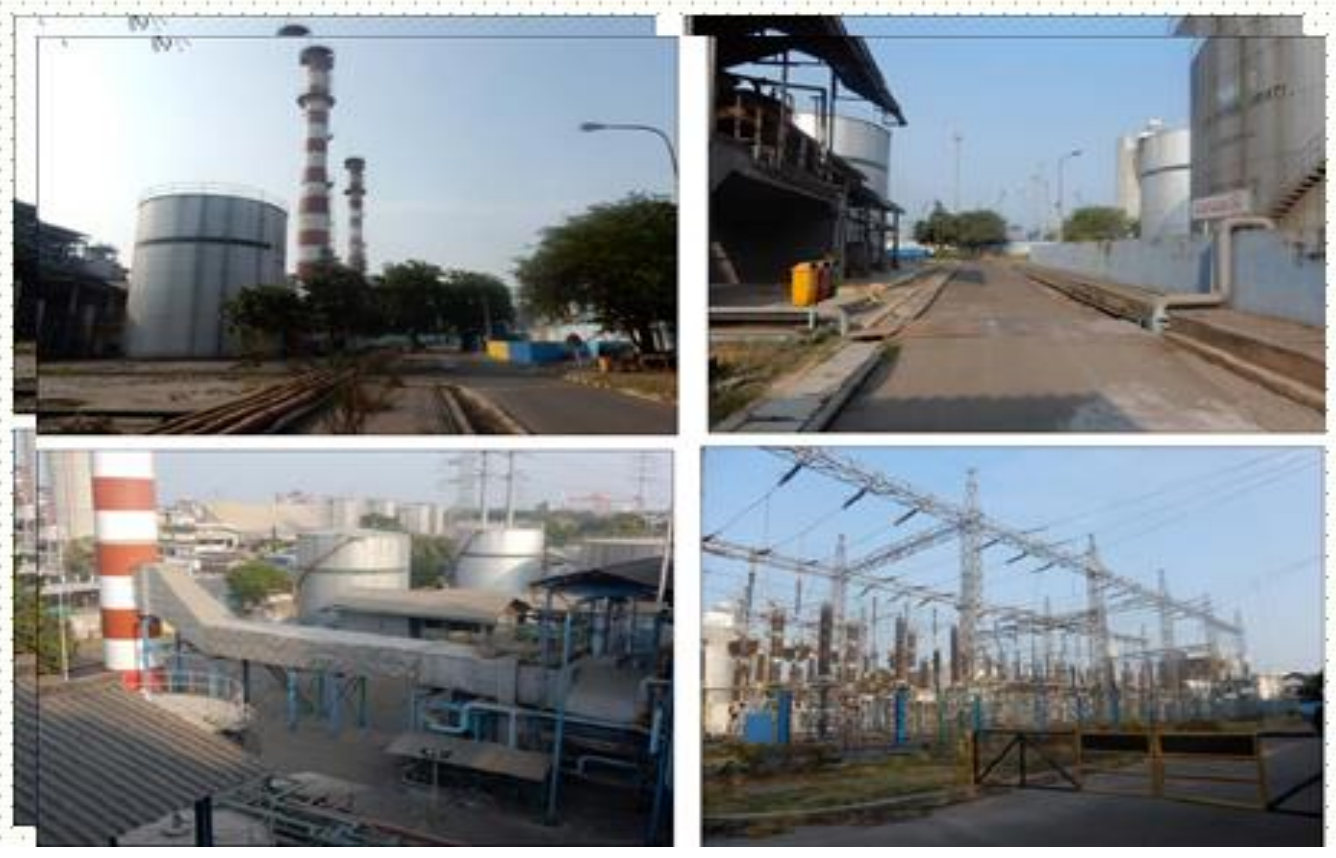

Pada Pembangunan Pembangkit Listrik Tenaga Gas dan Uap (PLTGU) Perak dengan kapasitas 500 MW, direncanakan di atas lahan seluas 5,2 $\mathrm{Ha}$ dan berlokasi di wilayah administrasi Kelurahan Perak Utara Kecamatan Pabean Cantikan, Kota Surabaya. Koordinat rencana kegiatan adalah S: $7^{0} 12$ ' 37.98"dan E: $112^{0} 43$ '27.98'. Pembangunan PLTGU Perak bagi pemerintah atau pemrakarsa bertujuan untuk menyediakan kebutuhan pasokan daya listrik yang terus meningkat; memperlancar kegiatan usaha atau industry melalui penyediaan daya listrik yang kontinyu; pemikul beban puncak (peaker) pada system kelistrikan Jawa Bali; dan mendukung program 35.000 MW yang dicanangkan pemerintah. Sedangkan bagi masyarakat rencana pembangunan ini bertujuan untuk memenuhi kebutuhan pasokan daya listrik bagi masyarakat di Jawa Timur dan sekitarnya; meningkatkan pendapatan penduduk disekitar lokasi penduduk melalui penyerapan tenaga kerja, serta memberikan peluang usaha bagi masyarakat sekitar pada tahap konstruksi dan operasional PLTGU. 
Gambar 3. Lokasi Wilayah Studi

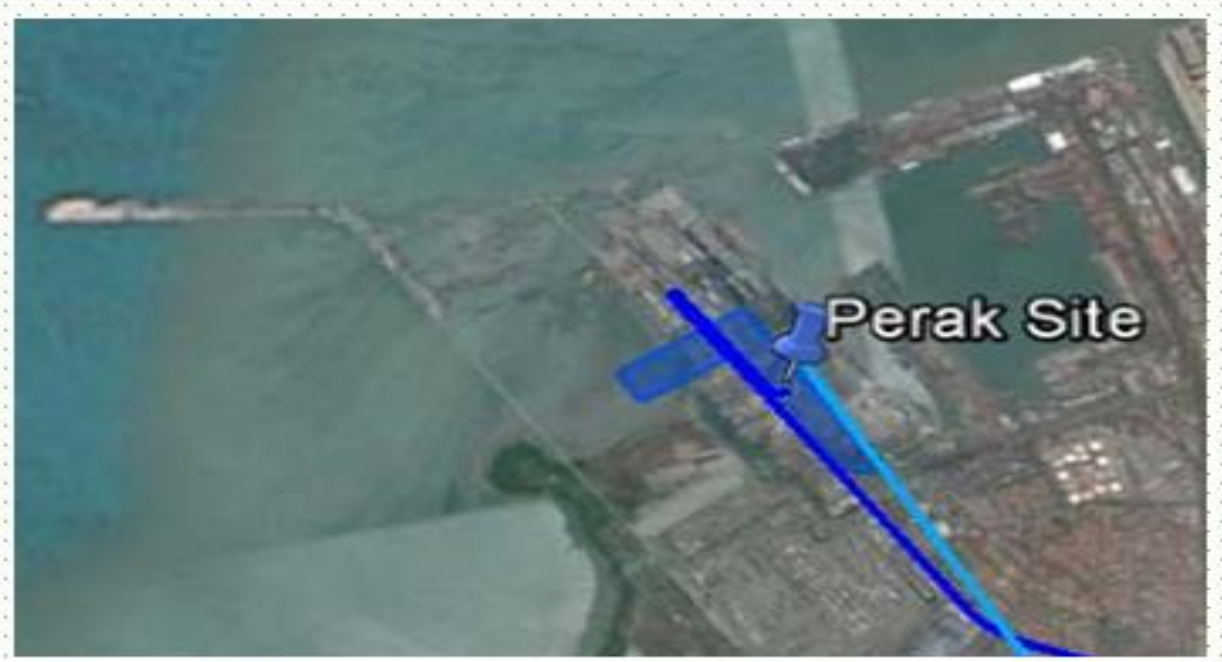

Setiap rencana usaha dan/atau kegiatan sebagai sebuah upaya untuk mewujudkan kesejahteraan manusia harus dilakukan dengan memadukan aspek lingkungan hidup, aspek sosial, dan aspek ekonomi ke dalam strategi pembangunan untuk menjamin keutuhan lingkungan hidup serta keselamatan, kemampuan, kesejahteraan, dan mutu hidup generasi masa kini dan generasi masa depan. Pembangunan selain akan menimbulkan dampak positif, juga dapat berdampak negatif berupa terjadinya perubahan lingkungan atau terjadi pencemaran dan kerusakan lingkungan. Dengan diterapkannya prinsip pembangunan berkelanjutan dan berwawasan lingkungan, dampak lingkungan yang diakibatkan oleh rencana kegiatan harus dianalisis sejak awal perencanaan sehingga langkah pengendalian dampak negatif dan pengembangan dampak positif dapat disiapkan sedini mungkin. Perangkat atau instrumen yang dapat digunakan untuk melakukan hal tersebut adalah Analisis Mengenai Dampak Lingkungan
(AMDAL) dan Upaya Pengelolaan Lingkungan Hidup dan Upaya Pemantauan Lingkungan Hidup (UKL - UPL), yang tercantum pada Pasal 22 Undang - Undang Nomor 32 Tahun 2009 tentang Perlindungan dan Pengelolaan Lingkungan Hidup (PPLH) yang menetapkan bahwa "Setiap Usaha dan/atau Kegiatan yang Berdampak Penting Wajib Memiliki AMDAL, sedangkan yang Tidak Berdampak Penting Diwajibkan Memiliki UKL UPL".

AMDAL adalah kajian mengenai dampak penting suatu usaha dan/atau kegiatan yang direncanakan pada lingkungan hidup yang diperlukan bagi proses pengambilan keputusan tentang penyelenggaraan usaha dan/atau kegiatan. Daftar jenis rencana usaha dan/atau kegiatan yang wajib memiliki AMDAL diatur berdasarkan Peraturan Menteri Negara Lingkungan Hidup Nomor 05 Tahun 2012 tentang Jenis Kegiatan/Usaha yang wajib memiliki AMDAL. Berdasarkan peraturan tersebut, rencana kegiatan Pembangunan PLTGU Perak di Kota Surabaya 
termasuk sebagai kegiatan yang wajib menyusun dokumen AMDAL. (Pembangunan PLTD/PLTG/PLTU/PLTGU dengan dengan daya $\geq 100$ MW dalam satu lokasi wajib dilengkapi dengan AMDAL), karena berpotensi menimbulkan dampak pada aspek fisik kimia, terutama pada kualitas udara emisi, ambient dan kualitas air (ceceran minyak pelumas, limbah bahang) serta air tanah. Selain itu juga berpotensi menimbulkan dampak pada aspek sosial, ekonomi, dan budaya terutama pada keresahan masyarakat, persepsi masyarakat (negatif maupun positif), gangguan kenyamanan, rekrutmen tenaga kerja pada saat kegiatan konstruksi maupun operasional, sehingga sering menimbulkan kendala dan hambatan rencana pembangunan tersebut oleh masyarakat di sekitar wilayah kegiatan. Banyak kasus rencana kegiatan pembangunan yang studi AMDALnya ditolak masyarakat, antara lain: Bandara Baru Kulonprogo dengan Pemrakarsa P.T.Angkasa Pura I; Amdal PLTU Rembang Jawa Tengah dengan Pemrakarsa P.T PLN Persero; Amdal Pabrik Semen di Pati Jawa Tengah dengan pemrakarsa P.T. Indocement Tunggal Perkasa; AMDAL Penambangan Pasir Besi dengan pemrakarsa P.T Jogja Magaza Iron (JMI), AMDAl Reklamasi Tanjung Benoa Bali dengan pemrakarsa P.T Tirta Wahana Bali Internasional (TWBI) dan masih banyak kasus yang lain). Penolakan oleh masyarakat tersebut diantaranya karena faktor persepsi negatif masyarakat terhadap rencana pembangunan. Oleh karena itu perlu sosialisasi rencana kegiatan secara baik dan mendalam kepada masyarakat terdampak baik langsung maupun tidak langsung serta pada institusi/dinas dan stakeholder terkait, agar supaya persepsi negatif terhadap rencana pembangunan tersebut menjadi persepsi positif. Hal tersebut sesuai dengan amanah Permen. LH No. 17 Tahun 2012 tentang keterlibatan masyarakat dalam proses AMDAL dan Izin Lingkungan perlu dilakukan Sosialisasi dan Pertemuan Konsultasi Masyarakat (PKM) rencana kegiatan pembangunan. Dengan demikian dalam rangka studi AMDAL PLTGU Perak perlu dilakukan sosialisasi kepada masyarakat yang diprairakan terkena dampak, untuk mengubah persepsi negatif masyarakat terhadap rencana pembangunan menjadi persepsi positif.

Persepsi merupakan suatu proses yang dimulai dari penglihatan hingga terbentuk tanggapan yang terjadi dalam diri individu sehingga individu sadar akan segala sesuatu dalam lingkungannya melalui indera-indera yang dimilikinya. Manusia sebagai makhluk sosial yang sekaligus juga makhluk individual, maka terdapat perbedaan antara individu yang satu dengan yang lainnya (Wolberg, 1967). Adanya perbedaan inilah yang antara lain menyebabkan mengapa seseorang menyenangi suatu obyek, sedangkan orang lain tidak senang bahkan membenci obyek tersebut. Hal ini sangat tergantung bagaimana individu menanggapi obyek tersebut dengan persepsinya. Pada kenyataannya sebagian besar sikap, tingkah laku dan penyesuaian ditentukan oleh persepsinya (Kamus Wikipedia). Persepsi pada hakikatnya adalah merupakan proses penilaian seseorang terhadap obyek tertentu. Menurut Young (1956) 
persepsi merupakan aktivitas mengindera, mengintegrasikan dan memberikan penilaian pada obyek-obyek fisik maupun obyek sosial, dan penginderaan tersebut tergantung pada stimulus fisik dan stimulus sosial yang ada di lingkungannya. Sensasi-sensasi dari lingkungan akan diolah bersama-sama dengan hal-hal yang telah dipelajari sebelumnya baik hal itu berupa harapan-harapan,nilai-nilai, sikap, maupun ingatan dan lain-lain. Branca (1965) mengemukakan: "Perceptions are orientative reactions to stimuli. They have in past been determined by the past history and the present attitude of the perceiver". Sedangkan menurut Wagito (1981) menyatakan bahwa persepsi merupakan proses psikologis dan hasil dari penginderaan serta proses terakhir dari kesadaran, sehingga membentuk proses berpikir. Sehingga persepsi terhadap sesuatu bisa bersifat negatif atau positif. Misalnya ketika berbicara dengan seseorang kita selalu menganalisa tiap katakatanya, sikapnya, tingkah lakunya dan mengamati ekspresi wajahnya. Hasilnya adalah sebuah persepsi mengenai orang tersebut. Jika ada beberapa hal yang tidak sesuai dengan pola pikir kita, maka persepsi kita mengenai dirinya menjadi negatif, dan sebaliknya jika kita menyukai idealismenya maka persepsi kita akan positif.

Tujuan dari kegiatan sosialisasi dan PKM dalam studi AMDAL adalah melindungi kepentingan masyarakat; memberdayakan masyarakat dalam pengambilan keputusan atas rencana kegiatan pembangunan PLTGU Perak yang berpotensi menimbulkan dampak lingkungan; memastikan adanya transparansi dalam keseluruhan proses AMDAL serta rencana kegiatan; menciptakan suasana kemitraan yang setara dengan semua pihak yang berkepentingan; menghormati hak-hak semua pihak yang berkepentingan untuk mendapatkan informasi dan mewajibkan semua pihak untuk menyampaikan informasi yang harus diketahui oleh pihak lain yang berkepentingan. Dengan maksud dan tujuan tersebut, maka diharapkan masyarakat di wilayah terdampak akan memiliki persepsi positif terhadap rencana pembangunan.

\section{Metode Pelaksanaan Kegiatan Sosialisasi dan PKM}

Metode pelaksanaan kegiatan sosialisasi dan PKM adalah menggunakan model pendekatan perspektif interaksional, dimana informasi yang disampaikan mendapat tanggapan, saran dan aspirasi masyarakat terdampak baik langsung maupun tidak langsung dari rencana kegiatan, sehingga didapatkan saling pengertian antara kedua belah pihak, baik masyarakat dengan pemrakarsa. Model pendekatan masyarakat dibangun dengan memberikan informasi secara jelas dengan bahasa yang persuasif yang mudah dimengerti oleh khalayak sasaran tentang rencana kegiatan baik teknis maupun nonteknis. Sedangkan sasaran kegiatan sosialisasi dan PKM ini adalah masyarakat/warga yang diperkirakan terdampak secara langsung atau pun tidak langsung dan tokoh masyarakat/pimpinan informal (Tokoh Masyarakat, Tokoh Agama, Karang Taruna, Pembina PKK, Kelompok 
Masyarakat/LPM, dan lain sebagainya), serta Muspika (Camat, Koramil, dan Polsek), pimpinan formal (Lurah, Sekretaris Lurah, Linmas, LKMK, RT, RW, dan lain sebagainya).

\section{Pembahasan Hasil Kegiatan Sosialisasi dan PKM}

Sebelum pelaksanaan kegiatan sosialisasi, dilakukan koordinasi oleh konsultan kegiatan dengan kecamatan dan kelurahan yang ketempatan untuk membahas teknis pelaksanaan sosialisasi. Disepakati kegiatan sosialisasi dan PKM dilaksanakan pada hari Selasa, pada tanggal 8 Nopember 2016, pukul 19.00 - 21.00 WIB di Ruang Balai Kelurahan Perak Utara, Kecamatan Pabean Cantikan - Kota Surabaya.

Pelaksanaan kegiatan sosialisasi dan PKM sebagai berikut: acara dibuka oleh Lurah Perak Utara, dilanjutkan dengan sambutan pemrakarsa kegiatan P.T. Indonesia Power, serta presentasi materi sosialisasi dan PKM rencana kegiatan Pembangunan PLTGU Perak oleh konsultan, LPPM - ITS. Kemudian dilanjutkan dengan diskusi yang dimoderatori dan dipandu oleh Lurah Perak Utara, sementara itu ketua dan anggota tim Studi AMDAL yang lain merespon pertanyaan, saran, masukan, dan tanggapan dalam diskusi tersebut.

Secara keseluruhan peserta Kegiatan Sosialisasi dan PKM studi AMDAL PLTGU Perak ini berjumlah 48 orang. Penjaringan aspirasi responden peserta kegiatan tersebut selain dari diskusi yang dilakukan pada acara pertemuan juga melalui kuesioner yang dibagikan. Pengisian kuesioner dipandu oleh tim studi AMDAL sehingga validitas data yang diisikan dalam kuesioner yang dibagikan dapat dipertanggungjawabkan. Sebanyak 36 (tiga puluh enam) responden, yaitu masyarakat terkena dampak baik langsung maupun tidak langsung mengisi dan menyerahkan kembali kuesioner yang dibagikan.

Hasil dari Kegiatan Sosialisasi dan PKM Studi AMDAL Rencana Pembangunan PLTGU Perak di Kelurahan Perak Utara - Kecamatan Pabean Cantikan, Kota Surabaya didiskripsikan sebagai berikut :

1. Identitas Responden Kegiatan Sosialisasi dan PKM

Kegiatan Sosialisasi dan PKM Studi AMDAL PLTGU Perak diikuti oleh Muspika setempat (Camat, Koramil, dan Polsek), Lurah dan aparat kelurahan, Lembaga Ketahanan Masyarakat Kelurahan (LKMK), Perlindungan Masyarakat (LINMAS), Tokoh Masyarakat, Tokoh Agama, anggota PKK dan Karang Taruna, dan masyarakat terdampak di wilayah studi. Untuk mendiskripsikan identitas responden, maka variabel yang digunakan adalah jenis kelamin, tingkat pendidikan, agama, usia, pekerjaan dan status responden sebagai berikut.

a. Jenis Kelamin Responden

Peserta atau responden kegiatan sosialisasi dan PKM Studi AMDAL PLTGU Perak yang mengembalikan kuesioner sebanyak 36 orang, yang terdiri dari 25 orang 
laki-laki $(69,44 \%)$ dan 11 orang perempuan

dalam

tabel

berikut

ini.

$(30,56 \%)$. Jenis kelamin responden disajikan

Tabel 1. Jenis Kelamin Responden

\begin{tabular}{|c|l|c|c|}
\hline No & Tingkat Pendidikan & Jumlah & Persentase (\%) \\
\hline 1 & Laki - Laki & 25 & 69,44 \\
\hline 2 & Perempuan & 11 & 30,56 \\
\hline \multicolumn{2}{|c|}{ Total } & 36 & 100,00 \\
\hline
\end{tabular}

(Sumber : Data Primer Kegiatan Sosialisasi dan PKM, November Tahun 2016)

responden.

Dari data tersebut dapat disimpulkan bahwa meskipun dalam menentukan keputusan masyarakat terkait dengan dampak lingkungan yang kemungkinan timbul akibat rencana kegiatan pembangunan masih didominasi oleh kaum laki-laki tetapi peran perempuan di wilayah studi telah diperhitungkan. Hal ini terlihat dari partisipasi kaum perempuan yang hadir dan ikut mengambil keputusan dalam kegiatan sosialisasi tersebut, meskipun jumlahnya tidak sama banyak dengan laki-laki, yaitu sebesar 30,56\% dari keseluruhan b. Tingkat Pendidikan Responden

Salah satu variabel untuk melihat kualitas sumberdaya manusia suatu daerah adalah tingkat pendidikan masyarakat di daerah tersebut. Mengetahui tingkat pendidikan responden sangat penting untuk melihat status sosial ekonomi, untuk membuat alat ukur selanjutnya (kuesioner ANDAL) yang mudah dipahami sesuai dengan tingkat pendidikan. Mayoritas responden berpendidikan SLTA yang disajikan dalam tabel 2 sebagai berikut.

Tabel 2. Tingkat Pendidikan Responden

\begin{tabular}{|c|l|c|c|}
\hline No & Tingkat Pendidikan & Jumlah & Persentase (\%) \\
\hline 1. & SLTP & 3 & 8,33 \\
\hline 2. & SLTA & 21 & 58,33 \\
\hline 3. & Sarjana Muda & 2 & 5,56 \\
\hline 3. & Sarjana & 7 & 19,44 \\
\hline 4. & Pasca Sarjana & 3 & 8,33 \\
\hline \multicolumn{2}{|c|}{ Total } & 36 & 100,00 \\
\hline
\end{tabular}

(Sumber : Data Primer Kegiatan Sosialisasi dan PKM, November Tahun 2016)

Dari data tingkat pendidikan responden peserta kegiatan sosialisasi dan PKM tersebut yang terbanyak respoden dengan tingkat pendidikan SLTA yaitu sebesar 58,33\% atau 21 responden. Kemudian diikuti pendidikan tingkat Sarjana sebesar $19,44 \%$ atau 7 responden, sedangkan jumlah responden dengan tingkat pendidikan Pasca Sarjana dan SLTP sama, yaitu sebesar 8,33\% atau masingmasing 3 responden. Dengan demikian dapat 
disimpulkan bahwa pendidikan responden di wilayah studi sudah cukup baik, pada umumnya pendidikan responden telah memenuhi kriteria wajib belajar 12 tahun.

Seperti yang telah disebutkan di atas, bahwa para peserta sosialisasi dan kegiatan PKM adalah masyarakat yang terdampak langsung yaitu yang bermukim $\pm 1-3 \mathrm{~km}$ dari lokasi kegiatan; dan masyarakat terdampak tidak langsung, yaitu di dalam wilayah studi tetapi agak jauh dari lokasi kegiatan serta dari stakeholder terkait. Dari latar belakang pendidikan para peserta kegiatan sosialisasi, dapat diketahui bahwa sebagian besar dari responden berpendidikan SLTA. Dengan tingkat pendidikan yang baik, mereka akan memiliki pemahaman yang baik pula terhadap pentingnya pembangunan. Selain itu, walaupun pendidikan cukup heterogen, dari tingkat SLTP sampai Pascasarjana, tetapi diskusi mengenai Studi AMDAL Rencana Pembangunan PLTGU Perak berjalan dengan kondusif dan lancar, karena warga mendukung rencana pembangunan tersebut, mereka merasa akan mendapatkan manfaat dari pembangunan PLTGU Perak.

c. Agama Responden

Agama tidak hanya merupakan salah satu variabel untuk melihat kondisi kependudukan/demografi suatu wilayah/daerah, melainkan juga salah satu variabel untuk melihat kondisi budaya, dan adat istiadat diwilayah tersebut serta pola hubungan sosial yang ada diwilayah tersebut. Agama responden peserta kegiatan sosialisasi dan PKM disajikan pada tabel dan gambar sebagai berikut.

Tabel 3. Agama Responden

\begin{tabular}{|c|l|c|c|}
\hline No & Agama & Jumlah & Persentase (\%) \\
\hline 1. & Islam & 34 & 94,44 \\
\hline 2. & Kristen & 2 & 5,56 \\
\hline & Total & 36 & 100,00 \\
\hline
\end{tabular}

(Sumber : Data Primer Kegiatan Sosialisasi dan PKM, November Tahun 2016)

Berdasarkan tabel 3 dapat diketahui bahwa mayoritas responden peserta kegiatan sosialisasi dan PKM beragama Islam, yaitu sebesar 94,44\% atau 34 responden. Agama Protestan sebanyak 2 responden atau $5,56 \%$.

\section{d. Usia Responden}

Variasi usia responden peserta kegiatan sosialisasi dan PKM Studi AMDAL PLTGU
Perak tersebar mulai dari usia $\leq 30$ tahun hingga $\geq 61$ tahun. Secara rinci usia responden disajikan dalam tabel 4. 
Tabel 4. Usia Responden

\begin{tabular}{|c|c|c|c|}
\hline No & Distribusi Umur Responden & Jumlah & Persentase (\%) \\
\hline 1. & $\leq 30$ & 2 & 5,56 \\
\hline 2. & $31-40$ & 10 & 27,78 \\
\hline 3. & $41-50$ & 11 & 30,56 \\
\hline 4. & $51-60$ & 9 & 25,00 \\
\hline 5 & $\geq 61$ & 4 & 11,11 \\
\hline \multicolumn{2}{|c|}{ Total } & 36 & 100,00 \\
\hline
\end{tabular}

(Sumber : Data Primer Kegiatan Sosialisasi PKM, November Tahun 2016)

Tingkat usia peserta kegiatan sosialisasi

\section{dan PKM Studi AMDAL Rencana}

Pembangunan PLTGU Perak terbanyak adalah tingkat usia (41-50) tahun yaitu sebesar $30,56 \%$ atau 11 responden. Dengan kondisi tingkat usia mayoritas responden di usia produktif maka dapat dikatakan bahwa daya tangkap peserta sosialisasi tersebut cukup tinggi dan mereka relatif memahami arti kegiatan pembangunan yang akan dilaksanakan oleh pemerintah. Sehingga sangat diharapkan bahwa jawaban atau penilaian yang diberikan responden pada koesioner yang diberikan penyusun studi AMDAL rencana pembangunan PLTGU adalah benar-benar sesuai dengan kondisi yang terjadi di wilayah studi.

\section{e. Pekerjaan Responden}

Jenis pekerjaan/mata pencaharian merupakan salah satu variabel untuk mengukur kondisi sosial-ekonomi masyarakat di suatu wilayah, oleh karena itu jenis pekerjaan merupakan salah satu kategori atau karakteristik yang penting untuk diketahui. Data pekerjaan dan tingkat pendidikan responden ini dapat digunakan sebagai pertimbangan pelaksanaan kegiatan Community Development (COMDEV) dan Corporate Social Responsibility (CSR) dari pemrakarsa kegiatan pada masyarakat di wilayah studi. Jenis pekerjaan responden peserta kegiatan sosialisasi dan PKM Studi AMDAL Rencana Pembangunan PLTGU Perak disajikan sebagai berikut.

Tabel 5. Pekerjaan Responden

\begin{tabular}{|c|l|c|c|}
\hline No & \multicolumn{1}{|c|}{ Pekerjaan Responden } & Jumlah & Persentase (\%) \\
\hline 1. & Pegawai Negeri sipil (PNS) & 10 & 27,78 \\
\hline 2. & Pedagang & 7 & 19,44 \\
\hline 3. & Nelayan & 2 & 5,56 \\
\hline 4. & TNI/POLRI & 2 & 5,56 \\
\hline 5. & Swasta & 9 & 25,00 \\
\hline 6. & Pensiunan & 3 & 8,33 \\
\hline 7. & Lainnya & 3 & 8,33 \\
\hline
\end{tabular}




\begin{tabular}{|c|c|c|c|}
\hline No & Pekerjaan Responden & Jumlah & Persentase (\%) \\
\hline \multicolumn{2}{|c|}{ Total } & 36 & 100,00 \\
\hline
\end{tabular}

(Sumber : Data Primer Kegiatan Sosialisasi PKM, November Tahun 2016)

Berdasarkan tabel 5 dapat diketahui bahwa status responden berdasarkan pekerjaan yang terbanyak adalah PNS (27,78\%) atau sebesar 10 responden dari masyarakat terdampak dan instansi terkait, kemudian diikuti oleh 9 responden $(25,00 \%)$ bekerja di sektor swasta, 7 responden $(19,44 \%)$ bekerja di sektor perdagangan, yang kemungkinan besar adalah masyarakat terdampak kegiatan secara langsung. Identitas responden berdasarkan pekerjaan lainnya adalah sebagai: Nelayan dan TNI/POLRI masing-masing 5,56\%, Pensiunan, dan pekerjaan lainnya masing-masing sebesar $8,33 \%$. a. Status Responden Terdampak

Dari 36 orang responden, sebanyak $66,67 \%$ atau 24 responden merupakan masyarakat yang terkena dampak langsung dari pembangunan PLTGU Perak, yang tinggal tidak jauh dari rencana kegiatan. Sedangkan $25,00 \%$ atau 9 responden merupakan masyarakat yang tidak terkena dampak langsung dari rencana kegiatan pembangunan. Kemudian sisanya $8,33 \%$ atau 3 responden tidak diketahui statusnya kerena tidak menjawab pertanyaan pada kuesioner seperti disajikan dalam tabel 6 sebagai berikut

Tabel 6. Status Responden

\begin{tabular}{|c|l|c|c|}
\hline No & \multicolumn{1}{|c|}{ Status Responden Terdampak } & Jumlah & Persentase (\%) \\
\hline 1. & Langsung & 24 & 66,67 \\
\hline 2. & Tidak Langsung & 9 & 25,00 \\
\hline 3. & Tidak Diketahui & 3 & 8,33 \\
\hline \multicolumn{2}{r|}{ Total } & 36 & 100,00 \\
\hline
\end{tabular}

(Sumber : Data Primer Kegiatan Sosialisasi dan PKM, November Tahun 2016)

\section{Sikap dan persepsi masyarakat terhadap rencana pembangunan PLTGU Perak}

Pendekatan pada masyarakat setempat mempunyai peran yang esensial untuk mengetahui seberapa penting dan seberapa berpengaruhnya keberadaan PLTGU Perak nantinya terhadap kondisi kehidupan mereka baik secara sosial maupun secara ekonomi. Oleh karena itu diperlukan penilaian sikap dan persepsi masyarakat terhadap rencana pembangunan tersebut setelah kegiatan sosialisasi. Berdasarkan hasil survei diperoleh hasil bahwa mayoritas responden, $32(88,89 \%)$ menyatakan setuju, mayoritas alasan mereka setuju adalah karena kebutuhan listrik masyarakat dan industri akan terpenuhi, intensitas pemadaman listrik akan berkurang, akan ada peluang kerja dan peluang berusaha, sehingga akan berdampak positif terhadap perekonomian. Sedangkan sebanyak 4 responden $(11,11 \%)$ ragu-ragu khawatir akan 
terjadi pencemaran lingkungan khususnya setuju. Adapun alasan setuju tersebut disajikan kebisingan, dan tidak ada masyarakat yang tidak pada tabel sebagai berikut.

Tabel 7. Alasan Responden setuju terhadap Rencana Pembangunan PLTGU Perak

\begin{tabular}{|c|l|c|c|}
\hline No & \multicolumn{1}{|c|}{ Alasan Setuju Thd Rencana Pembangunan } & Jumlah & Persentase (\%) \\
\hline 1. & Memenuhi kebutuhan listrik masyarakat dan industri & 21 & 65,63 \\
\hline 2. & $\begin{array}{l}\text { Pasokan listrik akan stabil dan intensitas pemadaman listrik akan } \\
\text { berkurang }\end{array}$ & 3 & 9,38 \\
\hline 3. & $\begin{array}{l}\text { Ada peluang kerja dan berusaha bagi masyarakat disekitar kegiatan } \\
\text { pada saat konstruksi dan operasi }\end{array}$ & 6 & 18,75 \\
\hline 4. & Akan berdampak positip terhadap perekonomian & 2 & 6,25 \\
\hline \multicolumn{1}{|c}{ Total } & 32 & 100,00 \\
\hline
\end{tabular}

(Sumber : Data Primer Kegiatan Sosialisasi dan PKM, November Tahun 2016)

Meskipun hampir semua responden setuju dan hanya sedikit yang ragu-ragu, responden peserta kegiatan sosialisasi dan PKM merasa khawatir dan ada pula yang merasa tidak khawatir terhadap tahapan pembangunan, yaitu: tahap prakonstruksi, tahap konstruksi dan tahap operasi yang ditampilkan dalam tabel 8 sebagai berikut

Tabel 8. Kekhawatiran Responden terhadap Rencana Pembangunan PLTGU Perak

\begin{tabular}{|c|c|c|c|}
\hline No & Kekhawatiran Responden & Jumlah & Persentase $(\%)$ \\
\hline \multicolumn{4}{|c|}{ I. Tahap prakonstruksi } \\
\hline 1. & Khawatir & 3 & 8,33 \\
\hline 2. & Tidak Khawatir & 33 & 91,67 \\
\hline \multicolumn{2}{|c|}{ Jumlah } & 36 & 100,00 \\
\hline \multicolumn{4}{|c|}{ II. Tahap Konstruksi } \\
\hline 1. & Khawatir & 7 & 19,44 \\
\hline 2. & Tidak Khawatir & 29 & 80,56 \\
\hline \multicolumn{2}{|c|}{ Jumlah } & 36 & 100,00 \\
\hline \multicolumn{4}{|c|}{ III.Tahap Operasi } \\
\hline & Khawatir & 5 & 13,89 \\
\hline & Tidak Khawatir & 31 & 86,11 \\
\hline \multicolumn{2}{|c|}{ Jumlah } & 36 & 100,00 \\
\hline
\end{tabular}

(Sumber : Data Primer Sosialisasi/Konsultasi Publik, November Tahun 2016)

Berdasarkan data pada tabel 8 dapat diketahui bahwa sebagian besar responden tidak merasa khawatir baik dari tahap prakonstruksi, tahap konstruksi dan tahap operasi. Kekhawatiran responden pada tahap prakonstruksi dari kegiatankegiatan: survei dan investigasi awal, sosialisasi rencana kegiatan pembangunan PLTGU Perak, dan kekhawatiran terutama terkait dengan kegiatan penyiapan lahan yang berupa pembongkaran bangunan lama (demolition), mereka khawatir terjadi gangguan keamanan dan kenyamanan bagi penduduk sekitar dan 
masyarakat yang melakukan kegiatan berusaha di sekitar instalasi PLTGU lama serta khawatir terjadi pencemaran udara; dinyatakan sebanyak 3 responden $(8,33 \%)$.

Sedangkan pada tahap konstruksi, terdapat 7 responden $(19,44 \%)$ yang merasa khawatir terhadap kegiatan penyebab dampak sebagai berikut: mobilisasi tenaga kerja, pembangunan jalan akses dan fasilitas penunjang, mobilisasi peralatan dan material, pembersihan lahan, pembangunan dan pengoperasian basecamp, penyediaan dan pengangkutan material konstruksi, pembangunan PLTGU, demobilisasi peralatan proyek, serta demobilisasi tenaga kerja. Penyebab dampak tersebut terutama terkait dengan perekrutan tenaga kerja, mereka khawatir masyarakat sekitar tidak dilibatkan, terjadi kerusakan jalan karena truk pengangkut material dan alat berat, pencemaran lingkungan serta kemacetan jalan.

Selanjutnya pada tahap operasi, terdapat 5 responden $(13,89 \%)$ yang merasa khawatir terhadap kegiatan penyebab dampak seperti: operasional dan pemeliharaan PLTGU Perak, yaitu khawatir terjadi radiasi SUTET di sekitar wilayah studi terutama daerah ring I atau yang berjarak $1-3 \mathrm{~km}$, khawatir terjadi kebisingan saat operasional turbine karena daya listrik yang dihasilkan sangat besar (500 MW), serta khawatir jika pembangunan unit pembangkit tidak standar, maka jika terjadi kecelakaan masyarakat di sekitar akan terimbas.

\section{Informasi rencana pembangunan PLTGU Perak}

Rencana pembangunan PLTGU Perak telah diawali dengan kegiatan studi Feasibility Study (FS) pada tahun 2015. Studi tersebut selalu diawali dengan koordinasi dengan stakeholder di wilayah studi, sehingga beberapa responden kegiatan sosialisasi dan PKM AMDAL PLTGU Perak ini telah mengetahui atau mendengar rencana pembangunan. Rekapitulasi informasi responden mengenai rencana pembangunan PLTGU Perak disajikan dalam tabel dan gambar sebagai berikut.

Tabel 9. Informasi Responden tentang Rencana Pembangunan

\begin{tabular}{|c|c|c|c|}
\hline No. & Tentang Informasi Rencana Pembangunan & Jumlah & Persentase (\%) \\
\hline 1. & Pernah Mendengar & 11 & 30,56 \\
\hline 2. & Tidak Pernah Mendengar & 25 & 69,44 \\
\hline \multicolumn{2}{|c|}{ Total } & $\mathbf{3 6}$ & $\mathbf{1 0 0 , 0 0}$ \\
\hline
\end{tabular}

(Sumber : Data Primer Kegiatan Sosialisasi dan PKM, November Tahun 2016)

Berdasarkan tabel 9 dapat diketahui bahwa cukup banyak responden 11 (30,56\%) sudah pernah mendengar informasi mengenai pembangunan PLTGU Perak mulai tahun 2015.
Sedangkan responden yang belum pernah mendengar informasi mengenai rencana pembangunan PLTGU Perak yaitu sebesar $69,44 \%$ atau 25 responden, sehingga perlu 
disosialisasikan. Sedangkan sumber informasi

tabel dan gambar sebagai berikut. rencana pembangunan PLTG Perak disajikan pada

Tabel 10. Sumber Informasi Responden tentang Rencana Pembangunan

\begin{tabular}{|c|l|c|c|}
\hline No. & \multicolumn{1}{|c|}{$\begin{array}{c}\text { Sumber Informasi tentang Rencana } \\
\text { Pembangunan }\end{array}$} & Jumlah & Persentase (\%) \\
\hline 1. & Camat, Lurah, RT/RW & 6 & 54,55 \\
\hline 2. & Pemrakarsa Kegiatan, P.T Indonesia Power & 3 & 27,27 \\
\hline 3. & Pemerintah Kota Surabaya & 1 & 9,09 \\
\hline 4 & Lainnya & 1 & 9,09 \\
\hline \multicolumn{2}{r}{ Total } & $\mathbf{1 1}$ & $\mathbf{1 0 0 , 0 0}$ \\
\hline
\end{tabular}

(Sumber : Data Primer Kegiatan Sosialisasi dan PKM, November Tahun 2016)

Berdasarkan tabel 10 dapat diketahui bahwa ada masyarakat $(30,56 \%)$ yang telah mengetahui rencana pembangunan PLTGU Perak, umumnya responden mengetahui informasi mengenai pembangunan tersebut dari Camat, Lurah, RT dan RW dinyatakan oleh serta dari pemkrakarsa kegiatan yaitu P.T.Indonesia Power dan dari sumber lain seperti Tokoh Masyarakat. Kemudian apabila ada persoalan di wilayah studi, biasanya diselesaikan melalui beberapa opsi yang diinginkan masyarakat sebagai berikut:

Tabel 11. Opsi Penyelesaian Permasalahan di Wilayah Studi

\begin{tabular}{|c|l|c|c|}
\hline No. & Opsi Penyelesaian Permasalahan di Wilayah Studi & Jumlah & Persentase (\%) \\
\hline 1. & Musyawarah dengan Tokoh Masyarakat & 13 & 36,11 \\
\hline 2. & Melalui Organisasi/Lembaga Desa & 2 & 5,56 \\
\hline 3. & Musyawarah dengan Perangkat Desa & 16 & 44,44 \\
\hline 4 & Lainnya & 5 & 13,89 \\
\hline \multicolumn{2}{r|}{ Total } & $\mathbf{3 6}$ & $\mathbf{1 0 0 , 0 0}$ \\
\hline
\end{tabular}

(Sumber : Data Primer Kegiatan Sosialisasi dan PKM, November Tahun 2016)

Jika terjadi permasalahan di wilayah studi, maka tokoh yang disegani dan menjadi jembatan dalam menyelesaikan permasalahan tersebut antara lain:
Lurah, RT, RW, LKMK, Karang Taruna, dll seperti yang disajikan pada tabel 12 sebagai berikut.

Tabel 12. Tokoh Yang Disegani Menyelesaikan Permasalahan di Wilayah Studi

\begin{tabular}{|c|l|c|c|}
\hline No. & \multicolumn{1}{|c|}{ Tokoh yang Disegani di Wilayah Studi } & Jumlah & Persentase (\%) \\
\hline 1. & Lurah/Aparat Desa & 22 & 61,11 \\
\hline
\end{tabular}




\begin{tabular}{|c|l|c|c|}
\hline 2. & Tokoh Masyarakat & 3 & 8,33 \\
\hline 3. & Tokoh Agama/Adat & 8 & 22,22 \\
\hline 4 & Lainnya & 3 & 8,33 \\
\hline \multicolumn{2}{r|}{ Total } & $\mathbf{3 6}$ & $\mathbf{1 0 0 , 0 0}$ \\
\hline
\end{tabular}

(Sumber : Data Primer Kegiatan Sosialisasi dan PKM, November Tahun 2016)

4. Saran, pendapat, dan tanggapan responden peserta kegiatan PKM

Setelah kegiatan PKM tersebut dilaksanakan, dapat dihimpun usulan, saran, pendapat dari diskusi dan tanggapan berdasarkan hasil kuesioner yang merupakan cerminan sikap dan persepsi serta harapan masyarakat terhadap rencana pembangunan PLTGU Perak sebagai berikut :

a. Dalam proses konstruksi hendaknya mempertimbangkan keamanan, kenyamanan, dan kesehatan pekerja maupun masyarakat sekitar kegiatan.

b. Meskipun tenaga kerja direkrut oleh kontraktor pemenang tender, masyarakat di sekitar kegiatan harus diutamakan sesuai dengan keterampilan yang dimilikinya untuk mengurangi pengangguran.

c. Pemasangan tiang pancang jangan sampai menimbulkan getaran dan bising pada saat konstruksi sehingga mengganggu masyarakat disekitar kegiatan.

d. Diupayakan supaya dicegah radiasi SUTET di sekitar wilayah studi yang dapat meresahkan masyarakat ketika operasional PLTGU.

e. Mengingat daya listrik yang dihasilkan besar (500 MW), turbin yang digunakan juga besar, maka kebisingan yang ditimbulkan pada kegiatan operasional harus ditangani secara cermat sehingga kebisingan bisa diturunkan dan tidak mengganggu kenyamanan masyarakat di sekitar kegiatan

f. Pembangunan infrastruktur pembangkit tersebut harus baik, sesuai spek dan desain (Detail Engineering Design) serta mempertimbangkan keselamatan lingkungan sekitar.

g. Memberi kesempatan masyarakat sekitar untuk melakukan usaha, seperti membuka warung, rumah makan, toko, jasa lainnya yang dapat memenuhi tukang pada saat konstruki maupun karyawan PLTGU pada saat operasi

h. Pemrakarsa kegiatan harus selalu berkoordinasi dengan wakil masyarakat di wilayah studi seperti: Camat, Lurah, RT, RW, dll serta keamanan POLSEK dan KORAMIL/BABINSA

i. Dampak terhadap lingkungan akibat operasional PLTGU Perak harus dikelola sesuai kajian yang dilakukan.

j. Ketika PLTGU akan dibangun, sosialisasi supaya dilanjutkan lagi pada tingkat masyarakat luas supaya mereka memahami dampak, baik positif maupun negatif yang ditimbulkan dari kegiatan pembangunan PLTGU Perak. 
k. Pada operasional PLTGU Perak, pemrakarsa P.T Indonesia Power hendaknya melakukan pengelolaan lingkungan sosial, berupa community development (Comdev) dan Corporate Social Responsibility (CSR) sesuai dengan kondisi dan minat masyarakat di wilayah studi.

I. Harapan masyarakat dengan akan dibangunnya 4 PLTGU, maka kebutuhan listrik masyarakat akan terpenuhi dngan harga yang murah.

m. Memperhatikan aspirasi masyarakat setempat dan mendengarkan suara rakyat terutama yang terkena dampak.

n. Diutamakan masyarakat setempat untuk menjadi tenaga kerja, melibatkan seluruh unsur pemerintahan dalam penyelesaian masalah, serta pembangunan dilaksanakan sesuai rencana.

\section{Kesimpulan}

Dari saran, pendapat, tanggapan masyarakat pada kegiatan sosialisasi dan PKM rencana pembangunan PLTGU Perak, serta sikap atau pun persepsi masyarakat setelah mengikuti kegiatan sosialisasi rencana kegiatan tersebut, disimpulkan bahwa ada perubahan persepsi positif terhadap rencana kegiatan pembangunan, hal ini terlihat dari mayoritas masyarakat setuju untuk segera dibangun, meskipun masih ada sebagian kecil masyarakat yang masih ragu-ragu terkait dengan dampak negatif dari pembangunan PLTGU tersebut. Dampak-dampak yang timbul pada masa prakonstruksi, konstruksi dan operasi seperti rekrutmen tenaga kerja yang tidak transparan, pencemaran terhadap lingkungan (udara, air, dan tanah), kebisingan, kerusakan jalan, dll. Untuk menjaga kepercayaan masyarakat di wilayah terdampak supaya memiliki persepsi positif terhadap kegiatan rencana pembangunan, maka dampak yang timbul harus dikelola dan dipantau. Dampak negatif diminimalkan sedangkan dampak positif dioptimalkan.

Pengelolaan dampak pada lingkungan akibat suatu kegiatan dikelola melalui pendekatan teknologi, pendekatan sosial-ekonomi-budaya, serta pendekatan institusi. Dan pengelolaan dampak hanya dilakukan pada dampak yang bersifat besar dan penting. Sedangkan pemantauan dampak lingkungan dilakukan untuk melihat efektifitas dan efisiensi pengelolaan lingkungan; dilakukan dengan beberapa perhatian terutama terkait dengan metode pemantauan ( metode pengumpulan dan analisa data), lokasi dan jadwal pemantauan

Konsep pengelolaan dampak pada lingkungan secara teknis misalnya: penutupan bak kendaraan pembawa material kelokasi proyek; pembersihan ban kendaraan proyek; melakukan pengaturan kecepatan dan tonase truk pengangkut; melakukan penyiraman jalan secara berkala; melakukan pengaturan lalu lintas menuju ke lokasi proyek; melakukan penanaman penghijauan disekitar PLTGU,dll.

Sedangkan konsep pengelolaan dampak pada lingkungan secara sosial-ekonomi-budaya misalnya: dengan cara membangun kemitraan dengan masyarakat sekitar sehingga terjadi 
keharmonisan hubungan yang lebih baik untuk mencegah adanya konflik dengan masyarakat sekitar; melakukan pembangunan dengan konsep pembangunan yang aman dan tidak meresahkan masyarakat; melakukan penyerapan tenaga kerja saat konstruksi atau operasional dengan memprioritaskan masyarakat sekitar yang mempunyai kompetensi dan keahlian yang dipersyaratkan oleh pihak pemrakarsa maupun kontraktor; adanya kerjasama dan partisipasi aktif yang baik antara pemrakarsa dan masyarakat sekitar serta tokoh masyarakat setempat; melakukan seluruh ketentuan dalam pengelolaan lingkungan sehingga masyarakat menerima kehadiran rencana pembangunan PLTGU.

Konsep pengelolaan dampak pada lingkungan secara institusi misalnya: melakukan koordinasi dan kerjasama secara terus menerus dengan aparat kelurahan, Koramil, dan Polsek selama proses pembangunan PLTGU Perak; serta melakukan koordinasi pelaksanaan pengelolaan lingkungan dan pemantauan lingkungan kegiatan tahap prakonstruksi, konstruksi, dan pascakonstruksi dengan dinas terkait atau pihakpihak lain yang sesuai dngan dampak yang diprakirakan terjadi.

\section{Daftar Pustaka}

Kurniawan, Rahmad. (2013). Analisa Efisiensi combined cycle 2-2-1 dan 1-1-1 PLTGU Sicanang. Belawan, Universitas Sumatra Utara.

Kementerian Lingkungan Hidup dan Kehutanan: Per.Men.LH No. 17 Tahun 2012 tentang Pedoman Keterlibatan Masyarakat dalam Proses Analisis Dampak Lingkungan Hidup dan Izin Lingkungan.

Kementerian Lingkungan Hidup dan Kehutanan: Per.Men.LH No. 5 Tahun 2012 tentang Jenis rencana usaha dan/atau kegiatan yang wajib dilengkapi dengan Analisis Mengenai Dampak Lingkungan.

Kementerian Lingkungan Hidup dan Kehutanan: PP No.27 Tahun 2012 tentang Izin Lingkungan.

Kementerian Lingkungan Hidup dan Kehutanan: Undang-Undang No.32 Tahun 2009 tentang Perlindungan dan Pengelolaan Lingkungan Hidup.

Wolberg. (1967). Edited by Striker,George and Gold, Jerold R: Comprehensive Handbook of Psychotherapy Integration. Springer Science+Business Media LLC.

Walgito,Bimo. (2004). Pengantar Psikologi Umum. Jogjakarta: ANDI

http://id.wikipedia.org/wiki/persepsi habibiarifin.blogspot.co.id/2010/05/persepsi.html pahrezaa.blogspot.org/category/tolak-reklamasiteluk-benoa usnalwandi.blogspot.com/2011/03/sikluskerjapltgu-gas-turbine.html www.walhibali.org/catagory/tolak-reklamasiteluk-benoa 